\title{
Recombinant Antibodies in Veterinary Medicine: An Update
}

\author{
Lorena Bustamante-Córdova ${ }^{\dagger}$, Edgar A. Melgoza-González ${ }^{\dagger}$ and Jesús Hernández* \\ Laboratorio de Inmunología, Centro de Investigación en Alimentación y Desarrollo, Hermosillo, Mexico
}

The production of recombinant antibodies has had a tremendous impact on several research fields, most prominently in biotechnology, immunology and medicine, enabling enormous advances in each. Thus far, a broad diversity of recombinant antibody ( $\mathrm{A} A \mathrm{~b}$ ) forms have been designed and expressed using different expression systems. Even though the majority of rAbs approved for clinical use are targeted to humans, advances in veterinary medicine seem promising. The aim of this mini-review is to present an update regarding the rAbs in veterinary medicine reported to date, as well as their potential use in diagnostics, prophylaxis and therapeutics. Full- and single-chain fragment variables are

OPEN ACCESS

Edited by:

Yashpal S. Malik,

Indian Veterinary Research Institute

(IVRI), India

Reviewed by:

Beatrix Foerster,

University Medical Center Utrecht,

Netherlands

Christi Swaggerty,

United States Department of

Agriculture, United States

*Correspondence:

Jesús Hernández

jhdez@ciad.mx

†These authors have contributed equally to this work.

Specialty section: This article was submitted to Veterinary Infectious Diseases, a section of the journal

Frontiers in Veterinary Science

Received: 26 May 2018

Accepted: 09 July 2018

Published: 27 July 2018

Citation:

Bustamante-Córdova L,

Melgoza-González EA and

Hernández J (2018) Recombinant

Antibodies in Veterinary Medicine: An

Update. Front. Vet. Sci. 5:175.

doi: 10.3389/fvets.2018.00175 the most common forms of rAbs developed for the detection, prevention and control of parasitic, bacterial and viral diseases, as well as pain and cancer treatment. Nonetheless, advances in research seem to be skewed toward economically important animals, such as pigs, cows, poultry and dogs. Although significant results have been obtained from the rAbs reported here, most have not been developed enough to be approved. Further research and clinical trials should be encouraged to enable important findings to fulfill their intended potential to improve animal well-being.

Keywords: recombinant antibodies, biotechnology, veterinary medicine, single-chain antibodies, nanobodies, chimeric antibodies

\section{INTRODUCTION}

Biotechnology has allowed for alternative methods of antibody $(\mathrm{Ab})$ production, thereby reducing or eliminating the use of experimental animals (1). The selection of an expression system, such as bacteria, yeast, insect and mammalian cell lines, and transgenic plants $(2,3)$, depends primarily on the type of $\mathrm{Ab}$ desired. Frenzel et al. (4) published an excellent review on the expression of recombinant antibodies, discussing the pros and cons of the most-used systems (4).

Abs are glycoproteins that consist of two heavy $(\mathrm{H})$ and two light $(\mathrm{L})$ chains united by disulfide bonds. Light and heavy chains have a variable $(\mathrm{V})$ and a constant $(\mathrm{C})$ region; in turn, the constant heavy domain $\left(\mathrm{C}_{\mathrm{H}}\right)$ is divided into three domains $\left(\mathrm{C}_{\mathrm{H} 1}-\mathrm{C}_{\mathrm{H} 3}\right)$ and in some cases, four domains. Variable regions contain "complementarity determining regions" (CDR) that determine the affinity and specificity of an $\mathrm{Ab}$. The union of variable domain of light chain-constant domain of light chain $\left(\mathrm{V}_{\mathrm{L}}-\mathrm{C}_{\mathrm{L}}\right)$ and variable domain of heavy chain-constant domain of heavy chain $\left(\mathrm{V}_{\mathrm{H}}-\mathrm{C}_{\mathrm{H} 1}\right)$ form the "antigen-binding fragment" (Fab). The rest of the $\mathrm{Ab}$ forms the fragment crystallizable region $(\mathrm{Fc})$ and gives the $\mathrm{Ab}$ its effector function (5). The above characteristics represent the classical structure of an $\mathrm{Ab}$.

Based on the classical structure of an $\mathrm{Ab}$, other forms of $\mathrm{rAb}$ have been developed (Figure 1). The most popular in veterinary medicine seems to be the single-chain fragment variable ( $\mathrm{scFv}$ ). The $\mathrm{scFv}$ comprises the $\mathrm{V}_{\mathrm{L}}-\mathrm{V}_{\mathrm{H}}$ joined by a short peptide linker (6). Another highly reported $\mathrm{rAb}$ is the singledomain antibody (sdAb) or nanobodies, which present the heavy variable region ( $\mathrm{VHH}$ ) only (7). 
Other rAbs, such as triabodies and tetrabodies (2), are not particularly reported in veterinary medicine (Figure 1). Hybrid rAbs, chimeric or "-nized," are common in veterinary medicine. $\mathrm{A}$ chimeric $\mathrm{Ab}$ typically consists of the $\mathrm{V}$ regions of one $\mathrm{Ab}$ and the $\mathrm{C}$ region of another. The "-nized" $\mathrm{Ab}$ comprises the original $\mathrm{Ab}$ and CDRs from other species, such as humanized or porcinized. The main advantage of a hybrid $\mathrm{rAb}$ is reduced immunogenicity while maintaining the specificity of CDRs (8).

Orthoclone (Muromonab-CD3) was the first monoclonal Ab (mAb) approved in humans (9). Since then, Abs have become predominant products in the human pharmaceutical market (10). Since 2015, 23\% of the drugs approved by the Food and Drug Administration in USA have been Abs, including humanized and chimeric, with just a few used in animals. This review presents an update of the rAbs reported in the field of veterinary medicine according to their use in diagnosis, prophylaxis and therapeutics in different species. However, there is an emphasis on rAbs in pigs and cows because they represent more prolific fields. Table $\mathbf{1}$ summarizes all rAbs described in this mini-review, showing the expression system, form, target species and main results. A discussion of the results describing only $\mathrm{rAb}$ production was omitted in the following sections.

\section{RECOMBINANT ANTIBODIES IN VETERINARY DIAGNOSIS}

\section{Pig}

Research for new diagnostic tests using rAbs have been concentrated on porcine circovirus type II (PVC2), classic swine fever virus (CSF), Brachyspira hyodysenteriae and Taenia spp. A commercial PVC2 vaccine was used to immunize a camel and produce a $\mathrm{sdAb}$ anti-Cap protein (11). This sdAb showed high specificity and sensitivity for the detection of PVC2 without cross reactivity with PCV1, porcine reproductive and respiratory syndrome virus (PRRSV) GP5 protein or CSF E2 protein. The sdAb was fused with alkaline phosphatase (sdAb-AP) to improve diagnosis, and the affinity and sensitivity were higher than those of the original sdAb (12). Recently, a porcinized $\mathrm{rAb}$ anti-E2 protein of CSFV was produced. This porcinized $\mathrm{rAb}$ was evaluated in diverse assays with good results and importantly, retained the ability to neutralize CSFV in vitro, suggesting that it has great potential as a diagnostic tool (13). Lobova et al. (14) described a scFv capable of detecting $B$. hyodysenteriae, an etiological agent of swine dysentery. After ELISA and immunofluorescent assay (IFA) evaluation, the authors concluded that this scFv can be used in new diagnostic tests (14). In the case of parasitic diseases, a sdAb showed no cross reactivity with $T$. saginata, $T$. hydatigena, $T$. crassiceps, and Trichinella spiralis antigens, allowing the specific diagnosis of Taenia solium infection (15).

\section{Cows}

The rAbs for the most important pathogens affecting bovines, including foot and mouth disease virus (FMDV), Mycobacterium bovis and bovine spongiform encephalopathy (BSE), have been evaluated by new diagnostic tests. Two scFvs specific for the $3 \mathrm{ABC}$ antigen have been reported to differentiate between vaccinated and infected animals with FMDV. Foord et al. (16) produced a chicken $s c F v$ specific for the $3 \mathrm{~B}$ region of the $3 \mathrm{ABC}$ antigen and concluded that scFv could be used in a FMDV differentiating infected from vaccinated animals (DIVA) test offering superior results compared with those of the $3 \mathrm{ABC}$ antigen in an ELISA, using sera from naïve and infected animals (16). Sharma et al. (17) validated a scFv in sandwich and competitive ELISAs and proposed it as an alternative to the diagnosis of FMDV (17). Other authors have produced a $\mathrm{scFv}$ anti-VP1 protein of FMDV in transgenic Tobacco plants (18). In the case of the bovine immunodeficiency virus (BIV), a scFv anti-capsid protein was produced and showed better sensitivity in ELISA and Western blot (WB) assays than did the mAb, which is considered the "gold standard" (19). A scFv antiHSP65) protein was conjugated to colloidal gold and evaluated in immunochromatographic tests (ICT) as a capture/secondary antibody to improve $M$. bovis diagnosis. This combination could detect the HSP65 protein dimer by ICT but not by ELISA. Later, this $\mathrm{scFv}$ was fused with a chicken $\mathrm{H}$ chain, and the stability was improved without affecting functionality (20). In another study, a sdAb produced in camels immunized with intracellular bacteria Brucella melitensis, which is responsible for Mediterranean fever in animals and humans, could recognize antigens of a $B$. melitensis in ELISA (21). Finally, recombinant chicken immunoglobulin Y (IgY) (Ab3-15 and Ab4-19) antiprion protein $\left(\mathrm{PrP}^{\mathrm{sc}}\right)$ was produced to diagnose BSE, showing that it can be used to diagnose BSE and other prion diseases (22).

\section{Others}

In poultry, a scFv specific for the avian influenza virus (AIV) was produced and evaluated by ELISA; it showed higher sensitivity and specificity than previously established protocols (23). Additionally, scFv anti-phosphoprotein of the Newcastle disease virus (NDV) showed potential as a detection tool in ELISA and WB (24). A similar scenario was reported for a scFv specific to the infectious bursal disease virus (IBDV) $(25,26)$ and a scFv specific to avian coccidiosis (27). Taking advantage of the similarities between the human epidermal growth factor receptor 2 (HER2) and its canine homologue protein, dog epidermal growth factor receptor (DER2), two rAbs with cross reactivity were produced, a Fc-sdAb and a GFP-sdAb. Recognition of HER2 and DER2 was evaluated by flow cytometry and IFA to detect breast cancer cells from humans (SKBR3) and dogs (SH1B and P114). Therefore, these rAbs can be used to identify malignant cells and have the potential to be used as immunotherapeutics in dogs and humans (28).

\section{RECOMBINANT ANTIBODIES IN IMMUNOPROPHYLAXIS}

The amount of research on $\mathrm{rAb}$ as a new immunoprophylaxis for pigs has been enormous compared with that for bovine or other species. Different forms of rAb for porcine epidemic diarrhea virus (PEDV), PRRSV, FMDV, African swine fever virus (ASFV), and Haemophilus parasuis have been produced and evaluated. 


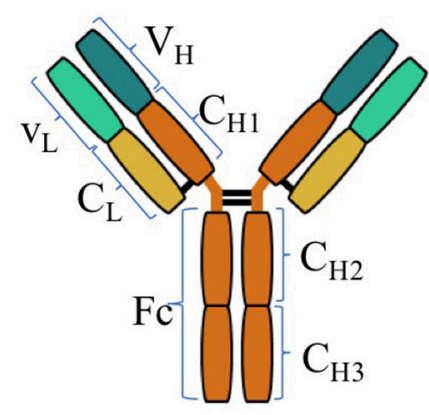

Full

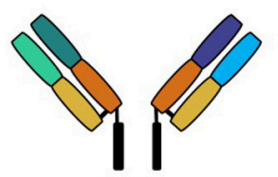

$\mathrm{Fab}_{2}$

bispecific

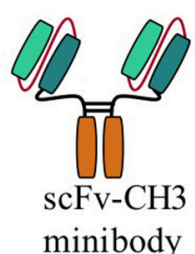

minibody

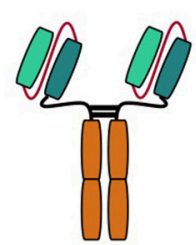

scFv-Fc

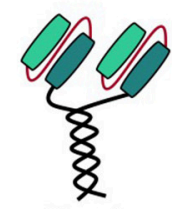

scFv-zipper

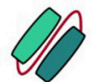

scFv

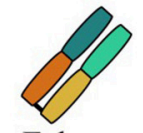

Fab

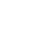

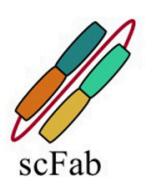

scFab

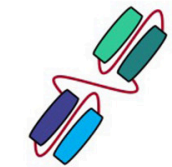

Bis-scFv

(bispecific)

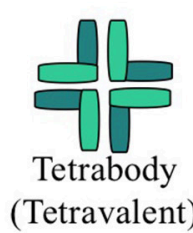

(Tetravalent)

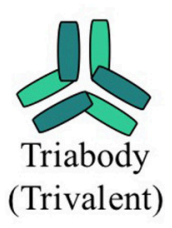

(Trivalent)

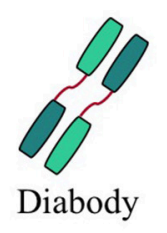

Diabody

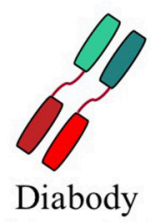

(bispecific)

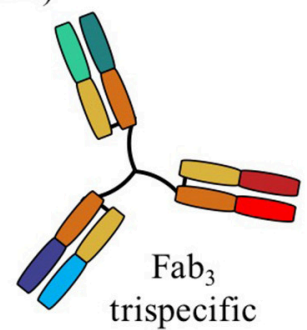

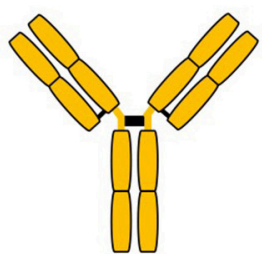

Specie 1

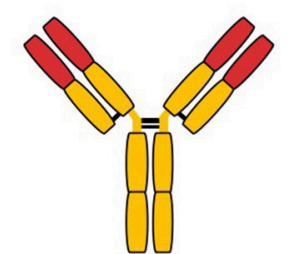

Chimeric

Porcine

Pig $\mathrm{x}$ mouse

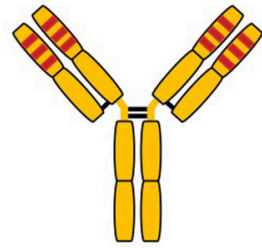

Specie1-nized

Porcinized

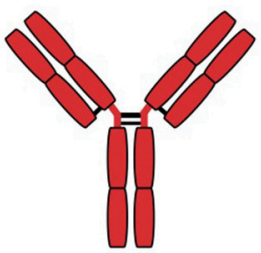

Specie 2

Murine
$\mathrm{sdAb}$

(VH/VHH)

FIGURE 1 | Graphic illustration of the diversity of recombinant antibody formats compared to a full, classic antibody. Abbreviations: variable domain of light chain ( $V_{\mathrm{L}}$ ), variable domain of heavy chain $\left(\mathrm{V}_{\mathrm{H}}\right)$, constant light domain $\left(\mathrm{C}_{\mathrm{L}}\right)$, constant heavy domain $\left(\mathrm{C}_{\mathrm{H}}\right)$, single-chain fragment variable (scFv), antigen-binding fragment (Fab), fragment crystallizable region (FC).

However, the majority of rAbs have been directed to PRRSV control.

\section{Pigs}

Antigen targeting to antigen-presenting cells, such as dendritic cells (DCs), has become an attractive approach in veterinary medicine (67). Other authors have evaluated this strategy but not with rAb (68-70). Subranamiam et al. has probed a scFvFc (mouse x pig) specific to DC-SIGN, DEC205 and Langerin receptors, and fused it with PRRSV structural proteins. The results showed that DEC205 targeting is the most successful in improving humoral and cellular responses while not inducing enough protective immunity $(29,30)$. In a similar approach, the administration of a rAb conjugated to peptides of PRRSV glycoprotein 4 (GP4) was used to target sialoadhesin (CD169), a receptor present in macrophages and monocytes. This study showed the production of anti-GP4 and neutralizing antibodies in immunized and challenged pigs (31). In other strategies, a sdAb specific to the non-structural protein 9 (nsp9) (Nb6) was produced to block viral infection. The authors demonstrated that viral replication was inhibited in a stable Marc-145 cell line expressing $\mathrm{Nb6}$, proving the potential of sdAb (Nb6) as a new form of protection against PRRSV (32). Similarly, a chimeric mouse $x$ pig antibody anti-linear GP5 epitope had neutralizing activity similar to that of the native mAb (ISU25C1) (33).

Certainly, most rAbs reported today are used to seek control of PRRSV. However, there are also other rAbs that can be used to control other diseases. A scFv-Fc (mouse $\mathrm{x}$ pig) specific for 
TABLE 1 | Summary of mentioned recombinant antibodies with potential use in veterinary medicine.

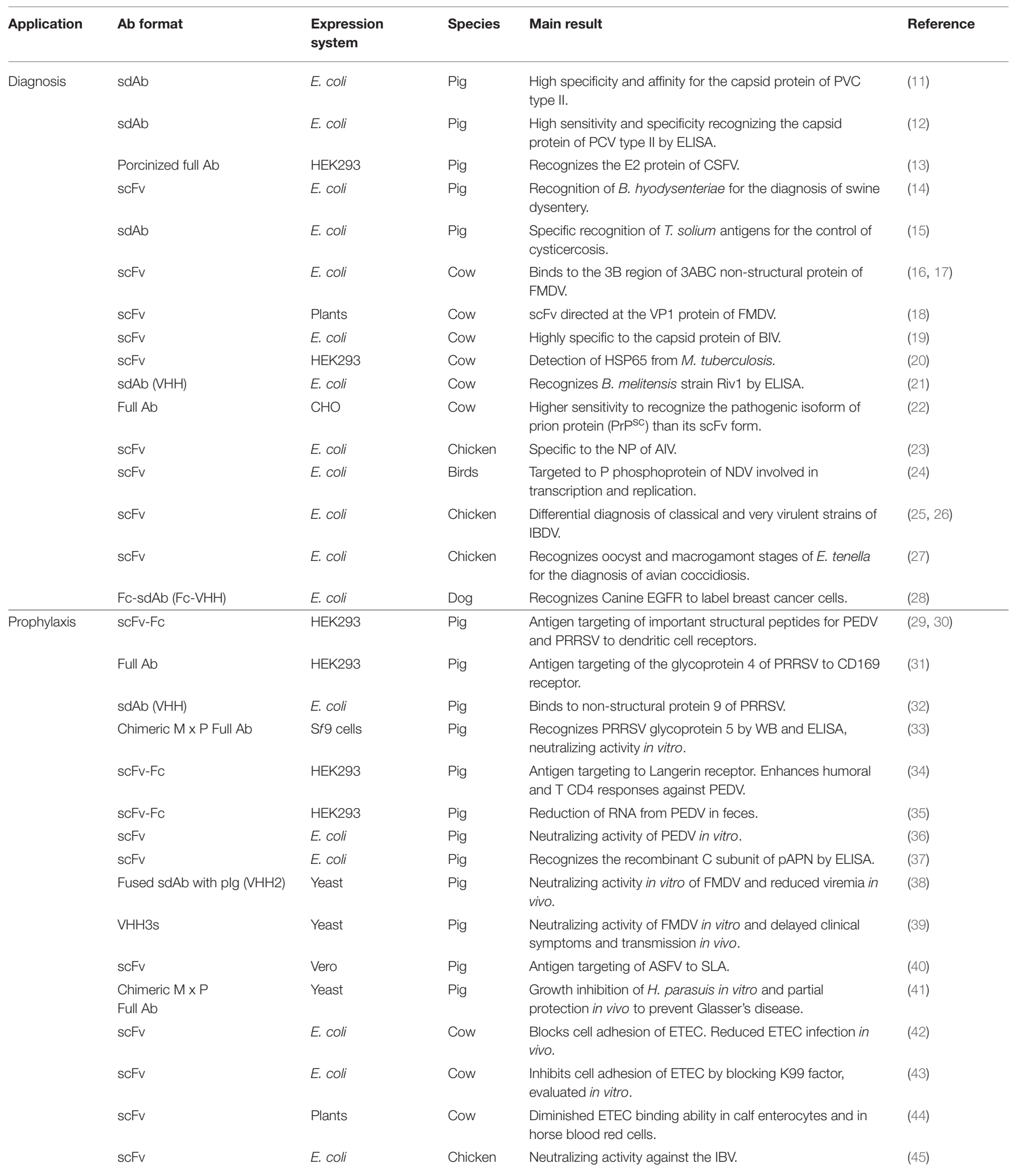


TABLE 1 | Continued

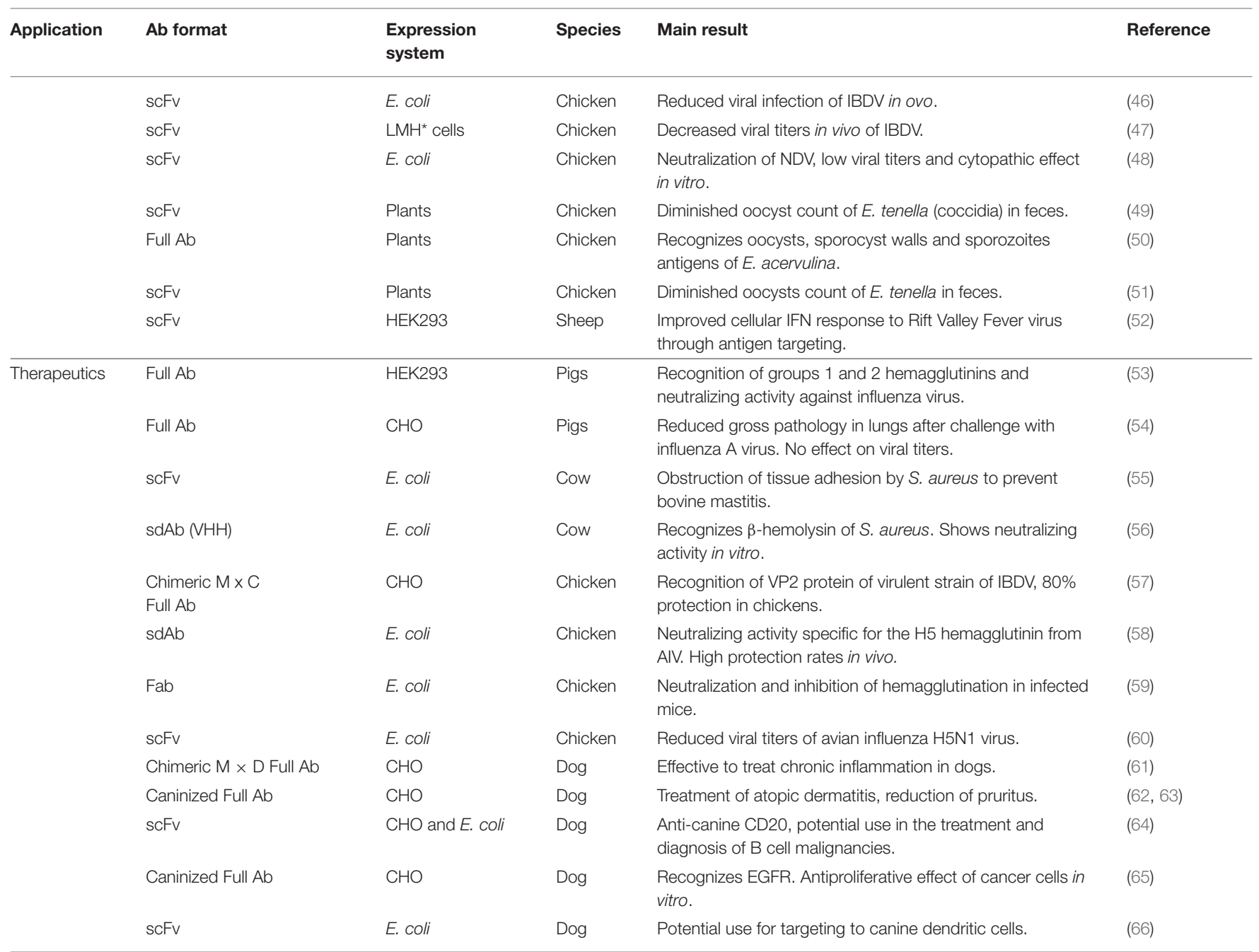

*LMH, Leghorn male hepatoma cell line.

the Langerin receptor expressed on DCs was fused with the spike protein of PEDV and used to immunize pigs. This strategy induced IgG and IgA responses, as well as a CD4 T cell immune response (34). When this $\mathrm{rAb}$ was tested in sows, an IgG response but not an IgA response was produced. Piglets born from these sows were challenged, and maternal immunity reduced fecal viral shedding, while clinical signs were unaffected (35). In other reports, a scFv anti-PEDV was tested in vitro and showed neutralizing activity, a reduced cytopathic effect and a reduction in viral replication titers (36). Similarly, a scFv against porcine aminopeptidase $\mathrm{N}$ (pAPN) could block the interaction of PEDV with pAPN, the receptor present in the intestinal epithelium, thus inhibiting virus entry to cells (37).

FMDV has also been a focus of rAb production. Harmsen et al. (71) evaluated a sdAb (VHH) as a tool to control FMD in pigs (71). Subsequently, different forms of sdAbs (VHH2s and VHH3s) were produced to increase its half-life and neutralizing activity compared with those of $\mathrm{VHH}$ in vitro. In an in vivo experiment, the authors compared $\mathrm{VHH} 2 \mathrm{~s}$ and $\mathrm{VHH} 3 \mathrm{~s}$ forms, showing the advantages of VHH3 forms; VHH3s delayed the development of clinical symptoms and FMDV transmission, basically for the doses, route of administration and higher neutralizing activity $(38,39)$. In an effort to control ASFV, a DNA vaccine encoding a scFv fused with p54 and p30 antigens was evaluated. Unfortunately, this strategy was unable to induce protection following a challenge (40).

For bacterial infections, only one $\mathrm{rAb}$ has been reported. This $\mathrm{rAb}$ (chimeric mouse $\times$ pig antibody) recognizes all serotypes of Haemophilus parasuis, inhibits the growth of the bacteria in vitro, and partially protects piglets against infection in vivo (41).

\section{Cows}

In contrast to those concerning pigs, there are fewer reports of rAbs being used to improve bovine diseases. Several attempts have been made to block Escherichia coli enterotoxigenic (ETEC) cell-adhesion capacity by targeting $\mathrm{K} 99$ fimbriae, a colonization factor. An in vivo evaluation of a scFv anti-F5 fimbriae (K99) resulted in less accumulation of fluid in the intestinal loops, 
indicative of a reduced ETEC infection in neonatal calves (42). Moreover, similar scFvs directed at K99 factor have been evaluated in vitro using horse red blood cells and calf enterocytes $(43,44)$ where hemagglutination and binding activity has been reduced.

\section{Others}

A scFv anti-infectious bronchitis virus (IBV) showed neutralizing activity (45); similarly, a scFv-Fc and scFv anti-infectious bursal disease virus (IBDV) reduced viral titers in vivo and in ovo (46, 47). NDV is a highly contagious viral infection that affects poultry and domestic birds. A scFv that recognizes NDV was produced and evaluated in vitro; the $\mathrm{Ab}$ showed neutralizing activity that resulted in reduced viral titers, as well as a lower cytopathic effect, in BHK21-infected cells (48). A scFv anti-Eimeria tenella and E. acervulina produced in pea plants and Nicotiana benthamiana, respectively $(49,50)$, reduced the number of oocysts in the feces of chickens fed with transformed plants, especially when feeding with pea plants (51). Additionally, IgA rAb anti-E. acervulina antigens have been produced in $N$. benthamiana plants as potential immunotherapy agents for young broilers in which vaccination is not always successful (50).

In sheep, a DNA vaccine encoding a scFv fused with Rift Valley Fever Virus Gn peptide was directed at DEC205 and CD11c receptors. Compared with targeting to $\mathrm{CD} 11 \mathrm{c}$ and untargeted treatment, targeting to DEC205 promoted IFN $\gamma$ production but showed an inefficient humoral response (52).

\section{RECOMBINANT ANTIBODIES FOR THERAPEUTIC PURPOSES}

The use of $\mathrm{rAb}$ for therapy has been mainly focused on dogs where personalized treatments are less challenging than those for farm animals. Examples include therapies for cancer and inflammatory processes.

\section{Pigs}

An anti-influenza virus antibody was obtained from a human donor after infection with $\mathrm{H} 1 \mathrm{~N} 1$ swine-origin influenza virus (SOIV). From this donor, a rAb named F16 was expressed and evaluated in several animal models. In mice and ferrets, F16 showed a therapeutic effect after a lethal challenge with H1N1 and H5N1 viruses, respectively (53). Nonetheless, when evaluated in pigs, F16 did not alter viral titers, although it reduced gross lung pathology when challenged (54).

\section{Cows}

Bovine mastitis is caused by a variety of pathogens including Staphylococcus aureus. Tissue adhesion involves multiple proteins, including fibronectin-binding factor A and clumping factor A. These two proteins were targeted using a scFv to obstruct the adhesion mechanisms; therefore, they have potential to be used to prevent and treat bovine mastitis (55). Similarly, a sdAb that could recognize and neutralize $\beta$-hemolysin from $S$. aureus was generated and evaluated in vitro to confirm its neutralizing activity (56).

\section{Others}

Therapy in poultry is, in most cases, not economically practical. However, the development of rAbs can simplify this practice. In this manner, a full-IgY rAb that can neutralize IBDV provides an $80 \%$ protection rate, in contrast to yolk antibody that offers only $40 \%$ protection in chickens challenged with IBDV (57). Similarly, a recombinant adenovirus (Ad5) containing the encoding sequence of a neutralizing sdAb specific for the $\mathrm{HA} 1$ domain of $\mathrm{H} 5$ virus was created. In vivo administration showed a $90-100 \%$ survival rate in lethally challenged mice (58). Additionally, a Fab that recognizes distinct HA0 hemagglutinin epitopes showed neutralizing activity and has great therapeutic potential (59). In this manner, a scFv anti-HA fused with truncated protamine (scFv-tP) designed to deliver siRNA was produced ( $\mathrm{scFv}-\mathrm{tP})$ and evaluated in vitro, showing a reduction in viral titers (60).

In some cases, human medicine can be adapted for use in veterinary medicine. An example is a chimeric dog x mouse $\mathrm{rAb}$ derived from a mouse anti-human nerve growth factor (NGF) $\mathrm{mAb}$ (72) used to treat chronic inflammation. In vivo, a single dose of this $\mathrm{rAb}$ showed effectiveness in reducing chronic pain similar to that of 7 daily doses of meloxicam in dogs, proving it to be a good alternative for prolonged therapeutic treatments (61). A full caninized rAb anti-canine IL-31, lokivetmab, has been produced and evaluated in clinical trials with outstanding results concerning the control of atopic dermatitis (AD) in dogs (62). Compared to a daily dose of $5 \mathrm{mg} / \mathrm{kg}$ of ciclosporin, a drug typically used to treat $\mathrm{AD}$, a single dose of $1 \mathrm{mg} / \mathrm{kg}$ ameliorated the symptoms of $\mathrm{AD}$ for a month (63). In the field of cancer, a scFv anti-canine CD20, a cell surface molecule expressed in normal and tumoral cells, was produced (64). Similarly, a caninized full $\mathrm{Ab}$ against epidermal growth factor receptor (EGFR) induces significant inhibition in proliferation in vitro and viability reduction in canine tumor cells that overexpress EGFR (65). Another anti-tumoral strategy is DC-based vaccination; a scFv capable of recognizing canine DCs has been produced for future use in vaccination and therapy (66).

\section{CONCLUSION}

The continuous search for alternative ways to control pathogens influenced the application of rAbs in veterinary medicine, which appears to be influenced by the type of animal production. Most reports describing the use of $\mathrm{rAbs}$ for diagnosis are concentrated in cows. Their use for treatment is concentrated in dogs, and use for immunoprophylaxis is concentrated in pigs. Unsurprisingly, in the case of pigs, most reports are concentrated on a solution for PRRSV; alternatively, therapeutic $\mathrm{rAb}$ is used to identify treatments for dog diseases (Table 1). There is a wide diversity of $\mathrm{rAb}$ forms (Figure 1), and not all have been described in veterinary medicine. However, $\mathrm{scFv}$, chimeric and $\mathrm{sdAb}$ are the most common forms of $\mathrm{rAbs}$ reported to date. In the upcoming years, the use of rAbs for the control of animal diseases will be a reality and will become a significant part of the economic world of pharmaceuticals. In summary, for the first time, the present mini-review describes the progress of $\mathrm{rAb}$ use in the 
field of veterinary medicine. This technology has not been fully exploited for diseases of economically impactful animals. The development of rAbs has been proven to be a promising tool in the improvement of animal health.

\section{AUTHOR CONTRIBUTIONS}

All authors listed have made a substantial, direct and intellectual contribution to the work, and approved it for publication.

\section{REFERENCES}

1. Shoemaker CB. When Will rAbs Replace mAbs in Labs? WB Saunders (2005).

2. Holliger P, Hudson PJ. Engineered antibody fragments and the rise of single domains. Nat Biotechnol. (2005) 23:1126-36. doi: 10.1038/nbt1142

3. Kunert R, Reinhart D. Advances in recombinant antibody manufacturing. Appl Microbiol Biotechnol. (2016) 100:3451-61. doi: 10.1007/s00253-016-7388-9

4. Frenzel A, Hust M, Schirrmann T. Expression of recombinant antibodies. Front Immunol. (2013) 4:217. doi: 10.3389/fimmu.2013.00217

5. Better M, Chang CP, Robinson RR, Horwitz AH. Escherichia coli secretion of an active chimeric antibody fragment. Science (1988) 240:1041-3. doi: $10.1126 /$ science. 3285471

6. Huston JS, Levinson D, Mudgett-Hunter M, Tai, M.-S., Novotný J, Margolies $\mathrm{MN}$, et al. Protein engineering of antibody binding sites: recovery of specific activity in an anti-digoxin single-chain Fv analogue produced in Escherichia coli. Proc Natl Acad Sci USA. (1988) 85:5879-83. doi: 10.1073/pnas.85.16. 5879

7. Hamers-Casterman C, Atarhouch T, Muyldermans S, Robinson G, Hammers C, Songa EB, et al. Naturally occurring antibodies devoid of light chains. Nature (1993) 363:446. doi: 10.1038/363446a0

8. Brüggemann $M$, Winter $G$, Waldmann $H$, Neuberger $M$. The immunogenicity of chimeric antibodies. J Exp Med. (1989) 170:2153-7. doi: 10.1084/jem.170.6.2153

9. Emmons C, Hunsicker L. Muromonab-CD3 (Orthoclone OKT3): the first monoclonal antibody approved for therapeutic use. Iowa Med. (1987) 77:7882.

10. Ecker DM, Jones SD, Levine HL. The therapeutic monoclonal antibody market. MAbs (2015). 7:9-14. doi: 10.4161/19420862.2015.989042.

11. Yang S, Shang Y, Yin S, Tian H, Chen Y, Sun S, et al. Selection and identification of single-domain antibody fragment against capsid protein of porcine circovirus type 2 (PCV2) from C. bactrianus. Vet Immunol Immunopathol. (2014) 160:12-9. doi: 10.1016/j.vetimm.2014.03.004

12. Yang S, Shang Y, Yin S, Wang D, Cai J, Gong Z, et al. A phagedisplayed single domain antibody fused to alkaline phosphatase for detection of porcine circovirus type 2. J Virol Methods (2015) 213:84-92. doi: 10.1016/j.jviromet.2014.11.023

13. Chen S, Li S, Sun H, Li Y, Ji S, Song K, et al. Expression and characterization of a recombinant porcinized antibody against the $\mathrm{E} 2$ protein of classical swine fever virus. Appl Microbiol Biotechnol. (2018) 102:961-70. doi: $10.1007 / \mathrm{s} 00253-017-8647-0$

14. Lobova D, CíŽek A, Celer V. The selection of single-chain Fv antibody fragments specific to Bhlp 29.7 protein of Brachyspira hyodysenteriae. Folia Microbiol. (2008) 53:517-20. doi: 10.1007/s12223-008-0081-3

15. Deckers N, Saerens D, Kanobana K, Conrath K, Victor B, Wernery $\mathrm{U}$, et al. Nanobodies, a promising tool for species-specific diagnosis of Taenia solium cysticercosis. Int J Parasitol. (2009) 39:625-33. doi: 10.1016/j.ijpara.2008.10.012

16. Foord AJ, Muller JD, Yu M, Wang LF, Heine HG. Production and application of recombinant antibodies to foot-and-mouth disease virus non-structural protein 3ABC. J Immunol Methods (2007) 321:142-51. doi: 10.1016/j.jim.2007.01.014

17. Sharma GK, Mahajan S, Matura R, Subramaniam S, Mohapatra JK, Pattnaik B. Production and characterization of single-chain antibody

\section{ACKNOWLEDGMENTS}

This work was supported by CONACyT-PN 2015 project number 248922. LB-C and EM-G received a scholarship from CONACyT. LB-C is part of the program Doctorado en Ciencias del Centro de Investigación en Alimentación y Desarrollo, A.C. EAMG is currently enrolled in Posgrado de Maestría en Ciencias de la Salud de la Universidad de Sonora.

(scFv) against $3 \mathrm{ABC}$ non-structural protein in Escherichia coli for serodiagnosis of foot and mouth disease virus. Biologicals (2014) 42:339-45. doi: 10.1016/j.biologicals.2014.08.005

18. Joensuu J, Brown K, Conley A, Clavijo A, Menassa R, Brandle J. Expression and purification of an anti-Foot-and-mouth disease virus single chain variable antibody fragment in tobacco plants. Transgenic Res. (2009) 18:685-96. doi: 10.1007/s11248-009-9257-0

19. Bhatia S, Gangil R, Gupta DS, Sood R, Pradhan H, Dubey S. Singlechain fragment variable antibody against the capsid protein of bovine immunodeficiency virus and its use in ELISA. J Virol Methods (2010) 167:6873. doi: 10.1016/j.jviromet.2010.03.012

20. Wemmer S, Mashau C, Fehrsen J, Van Wyngaardt W, Duplessis DH. Chicken scFvs and bivalent scFv-CH fusions directed against HSP65 of Mycobacterium bovis. Biologicals (2010) 38:407-14. doi: 10.1016/j.biologicals.2010.02.002

21. Abbady A, Al-Mariri A, Zarkawi M, Al-Assad A, Muyldermans S. Evaluation of a nanobody phage display library constructed from a Brucellaimmunised camel. Veterinary Immunol Immunopathol. (2011) 142:49-56. doi: $10.1016 /$ j.vetimm.2011.04.004

22. Miyamoto K, Shimamoto T, Aosasa M, Kimura S, Nakamura N, Okubo Y, et al. Development of recombinant chicken IgY from single chain fragment of variable region for diagnosis of BSE. Biologicals (2007) 35:31-4. doi: 10.1016/j.biologicals.2006.01.003

23. Sengupta D, Shaikh A, Bhatia S, Pateriya A, Khandia R, Sood R, et al. Development of single-chain $\mathrm{Fv}$ against the nucleoprotein of type A influenza virus and its use in ELISA. J Virol Methods (2014) 208:129-37. doi: 10.1016/j.jviromet.2014.08.009

24. Li B, Ye J, Lin Y, Wang M, Jia R, Zhu J. Selection and characterization of singlechain recombinant antibodies against phosphoprotein of newcastle disease virus. Biologicals (2014) 42:285-9. doi: 10.1016/j.biologicals.2014.05.006

25. Sapats S, Gould G, Trinidad L, Parede LH, David C, Ignjatovic J. An ELISA for detection of infectious bursal disease virus and differentiation of very virulent strains based on single chain recombinant chicken antibodies. Avian Pathol. (2005) 34:449-55. doi: 10.1080/03079450500367765

26. Sapats S, Trinidad L, Gould G, Heine H, Van Den Berg T, Eterradossi N, et al. Chicken recombinant antibodies specific for very virulent infectious bursal disease virus. Arch Virol. (2006) 151:1551-66. doi: 10.1007/s00705-0060729-8

27. Réfega S, Cluzeaud M, Péry P, Labbé M, Girard-Misguich F. Production of a functional chicken single-chain variable fragment antibody derived from caecal tonsils B lymphocytes against macrogamonts of Eimeria tenella. Veter Immunol Immunopathol. (2004) 97:219-30. doi: $10.1016 /$ j.vetimm.2003.09.008

28. Mazzega E, De Marco A. Engineered cross-reacting nanobodies simplify comparative oncology between humans and dogs. Veter Compar Oncology (2018) 16, E202-6. doi: 10.1111/vco.12359

29. Subramaniam S, Pineyro P, Derscheid RJ, Madson DM, Magstadt DR, Meng XJ. Dendritic cell-targeted porcine reproductive and respiratory syndrome virus (PRRSV) antigens adjuvanted with polyinosinic-polycytidylic acid (poly (I:C)) induced non-protective immune responses against heterologous type 2 PRRSV challenge in pigs. Vet Immunol Immunopathol. (2017) 190:18-25. doi: 10.1016/j.vetimm.2017.07.003

30. Subramaniam S, Pineyro P, Tian D, Overend C, Yugo DM, Matzinger $\mathrm{SR}$, et al. In vivo targeting of porcine reproductive and respiratory syndrome virus antigen through porcine DC-SIGN to dendritic cells elicits 
antigen-specific CD4T cell immunity in pigs. Vaccine (2014) 32:6768-75. doi: 10.1016/j.vaccine.2014.10.005

31. Ooms K, Van Gorp H, Botti S, Van Gaever T, Delputte PL, Nauwynck HJ. Evaluation of viral peptide targeting to porcine sialoadhesin using a porcine reproductive and respiratory syndrome virus vaccination-challenge model. Virus Res. (2013) 177:147-55. doi: 10.1016/j.virusres.2013.07.019

32. Liu H, Wang Y, Duan H, Zhang A, Liang C, Gao J, et al. An intracellularly expressed Nsp9-specific nanobody in MARC-145 cells inhibits porcine reproductive and respiratory syndrome virus replication. Veter Microbiol. (2015) 181:252-60. doi: 10.1016/j.vetmic.2015.10.021

33. Jar AM, Osorio FA, López OJ. Mousex pig chimeric antibodies expressed in Baculovirus retain the same properties of their parent antibodies. Biotechnol Prog. (2009) 25:516-23. doi: 10.1002/btpr.113

34. Subramaniam S, Cao D, Tian D, Cao QM, Overend C, Yugo DM, et al. Efficient priming of CD4 $\mathrm{T}$ cells by Langerin-expressing dendritic cells targeted with porcine epidemic diarrhea virus spike protein domains in pigs. Virus Res. (2017) 227:212-9. doi: 10.1016/j.virusres.2016.10.007

35. Subramaniam S, Yugo DM, Heffron CL, Rogers AJ, Sooryanarain H, Leroith $\mathrm{T}$, et al. Vaccination of sows with a dendritic cell-targeted porcine epidemic diarrhea virus S1 protein-based candidate vaccine reduced viral shedding but exacerbated gross pathological lesions in suckling neonatal piglets. J Gen Virol. (2018) 99:230-9. doi: 10.1099/jgv.0.001001

36. Pyo, H.-M., Kim, I.-J., Kim, S.-H., Kim, H.-S., Cho, S.-D., Cho, I.-S., et al. Escherichia coli expressing single-chain Fv on the cell surface as a potential prophylactic of porcine epidemic diarrhea virus. Vaccine (2009) 27:2030-6. doi: $10.1016 /$ j.vaccine.2009.01.130

37. Sun D, Shi H, Chen J, Shi D, Zhu Q, Zhang H, et al. Generation of a mouse scFv library specific for porcine aminopeptidase $\mathrm{N}$ using the T7 phage display system. J Virol Methods (2012) 182:99-103. doi: 10.1016/j.jviromet.2012.03.021

38. Harmsen MM, Fijten HP, Dekker A, Eble PL. Passive immunization of pigs with bispecific llama single-domain antibody fragments against foot-andmouth disease and porcine immunoglobulin. Vet Microbiol. (2008) 132:56-64. doi: 10.1016/j.vetmic.2008.04.030

39. Harmsen MM, Fijten HP, Engel B, Dekker A, Eble PL. Passive immunization with llama single-domain antibody fragments reduces foot-andmouth disease transmission between pigs. Vaccine (2009) 27:1904-11. doi: 10.1016/j.vaccine.2009.01.110

40. Argilaguet J, Perez-Martin E, Gallardo C, Salguero F, Borrego B, Lacasta A, et al. Enhancing DNA immunization by targeting ASFV antigens to SLA-II bearing cells. Vaccine (2011) 29:5379-85. doi: 10.1016/j.vaccine.2011.05.084

41. Chai Z, Fu F, Jiang F, Tian H, Wang Z, Zheng N, et al. Development of a neutralizing mouse-pig chimeric antibody with therapeutic potential against Haemophilus parasuis in Pichia pastoris. FEMS Microbiol Lett. (2014) 354:85-91. doi: 10.1111/1574-6968.12437

42. Sahagun-Ruiz A, Velazquez LV, Bhaskaran S, Jay CM, Morales-Salinas E, Rathore K, et al. Reduction of enterotoxin induced fluid accumulation in ileal loops of neonatal calves with anti-F5 fimbriae recombinant antibody. Vet Res Commun. (2015) 39:229-36. doi: 10.1007/s11259-015-9646-1

43. Golchin M, Aitken R. Isolation by phage display of recombinant antibodies able to block adherence of Escherichia coli mediated by the K99 colonisation factor. Vet Immunol Immunopathol. (2008) 121, 321-331. doi: 10.1016/j.vetimm.2007.10.005

44. Sunilkumar G, Waghela SD, Campbell LM, Rathore KS. Expression of anti-K99 scFv in transgenic rice tissues and its functional characterization. Transgenic Res. (2009) 18:347-60. doi: 10.1007/s11248-008-9223-2

45. Lin Y, Li B, Ye J, Wang M, Wang J, Zhang Y, et al. Neutralization analysis of a chicken single-chain variable fragment derived from an immune antibody library against infectious bronchitis virus. Viral Immunol. (2015) 28:397-404. doi: 10.1089/vim.2014.0104

46. Guo X, Cao H, Wang Y, Liu Y, Chen Y, Wang N, et al. Screening scFv antibodies against infectious bursal disease virus by co-expression of antigen and antibody in the bacteria display system. Vet Immunol Immunopathol. (2016) 180:45-52. doi: 10.1016/j.vetimm.2016.09.004

47. Greenall SA, Tyack SG, Johnson MA, Sapats SI. Antibody fragments, expressed by a fowl adenovirus vector, are able to neutralize infectious bursal disease virus. Avian Pathol. (2010) 39:339-48. doi: $10.1080 / 03079457.2010 .507239$
48. Li B, Ye J, Lin Y, Wang M, Zhu J. Preparation and identification of a single-chain variable fragment antibody against Newcastle diseases virus F48E9. Vet Immunol Immunopathol. (2014) 161:258-64. doi: 10.1016/j.vetimm.2014.08.009

49. Khalafalla RE, Daugschies A. In vivo evaluation of anticoccidial effect of antibody fragments expressed in pea (Pasum sativum) on Eimeria tenella sporozoites. Parasitol Res. (2010) 107:983-6. doi: 10.1007/s00436-010-1964-1

50. Wieland WH, Lammers A, Schots A, Orzáez DV. Plant expression of chicken secretory antibodies derived from combinatorial libraries. J Biotechnol. (2006) 122:382-91. doi: 10.1016/j.jbiotec.2005.12.020

51. Zimmermann J, Saalbach I, Jahn D, Giersberg M, Haehnel S, Wedel $\mathrm{J}$, et al. Antibody expressing pea seeds as fodder for prevention of gastrointestinal parasitic infections in chickens. BMC Biotechnol. (2009) 9:79. doi: $10.1186 / 1472-6750-9-79$

52. Chrun T, Lacote S, Urien C, Jouneau L, Barc C, Bouguyon E, et al. A rift valley fever virus $\mathrm{Gn}$ ectodomain-based DNA vaccine induces a partial protection not improved by APC targeting. NPJ Vaccines (2018) 3:14. doi: 10.1038/s41541-018-0052-x

53. Corti D, Voss J, Gamblin SJ, Codoni G, Macagno A, Jarrossay D, et al. A neutralizing antibody selected from plasma cells that binds to group 1 and group 2 influenza A hemagglutinins. Science (2011) 333:850-6. doi: $10.1126 /$ science. 1205669

54. Morgan SB, Holzer B, Hemmink J, Salguero FJ, Schwartz JC, Agatic G, et al. Therapeutic administration of broadly neutralizing FI6 antibody reveals lack of interaction between human IgG1 and pig Fc receptors. Front Immunol. (2018) 9:865. doi: 10.3389/fimmu.2018.00865

55. Wang M, Zhang Y, Li B, Zhu J. Construction of scFv that bind both fibronectin-binding protein A and clumping factor A of Stapylococcus aureus. Res Vet Sci. (2015) 100:109-14. doi: 10.1016/j.rvsc.2015.02.012

56. Jangra P, Singh A. Staphylococcus aureus $\beta$-hemolysin-neutralizing singledomain antibody isolated from phage display library of Indian desert camel. Asian Pacific J Trop Med (2010) 3:1-7. doi: 10.1016/S1995-7645(10)60020-X

57. Zhang Y, Yin J, Li T, Zhou B, Xu P, Che R, et al. A recombinant avian antibody against VP2 of infectious bursal disease virus protects chicken from viral infection. Res Vet Sci (2017) 114:194-201. doi: 10.1016/j.rvsc.2017.04.003

58. Tutykhina IL, Sedova ES, Gribova IY, Ivanova TI, Vasilev LA, Rutovskaya $\mathrm{MV}$, et al. Passive immunization with a recombinant adenovirus expressing an HA (H5)-specific single-domain antibody protects mice from lethal influenza infection. Antiviral Res. (2013) 97:318-28. doi: 10.1016/j.antiviral.2012.12.021

59. Pitaksajjakul P, Lekcharoensuk P, Upragarin N, Barbas CF, Ibrahim MS, Ikuta $\mathrm{K}$, et al. Fab MAbs specific to HA of influenza virus with H5N1 neutralizing activity selected from immunized chicken phage library. Biochem Biophys Res Commun. (2010) 395:496-501. doi: 10.1016/j.bbrc.2010.04.040

60. Zhang T, Wang, C.-Y., Zhang W, Gao, Y.-W., Yang, S.-T., Wang, T. C., et al. Generation and characterization of a fusion protein of singlechain fragment variable antibody against hemagglutinin antigen of avian influenza virus and truncated protamine. Vaccine (2010) 28:3949-55. doi: 10.1016/j.vaccine.2010.03.045

61. Gearing DP, Virtue ER, Gearing RP, Drew AC. A fully caninised anti-NGF monoclonal antibody for pain relief in dogs. BMC Vet Res. (2013) 9:226. doi: $10.1186 / 1746-6148-9-226$

62. Michels GM, Walsh KF, Kryda K, Mahabir SP, Walters RR, Hoevers JD, et al. A blinded, randomized, placebo-controlled trial of the safety of lokivetmab (ZTS- 00103289), a caninized anti-canine IL-31 monoclonal antibody, in client owned dogs with atopic dermatitis. Vet Dermatol. (2016) 27:505-e136. doi: $10.1111 /$ vde. 12364

63. Moyaert H, Van Brussel L, Borowski S, Escalada M, Mahabir SP, Walters $\mathrm{RR}$, et al. A blinded, randomized clinical trial evaluating the efficacy and safety of lokivetmab compared to ciclosporin in client-owned dogs with atopic dermatitis. Vet Dermatol. (2017) 28:593. doi: 10.1111/vde.12478

64. Jain S, Aresu L, Comazzi S, Shi J, Worrall E, Clayton J, et al. The development of a recombinant $\mathrm{scFv}$ monoclonal antibody targeting canine CD20 for use in comparative medicine. PLoS ONE (2016) 11:e0148366. doi: 10.1371/journal.pone. 0148366

65. Singer J, Fazekas J, Wang W, Weichselbaumer M, Matz M, Mader A, et al. Generation of a canine anti-EGFR (ErbB-1) antibody for passive immunotherapy in dog cancer patients. Molecular Cancer Ther. (2014) 13:1777-90. doi: 10.1158/1535-7163.MCT-13-0288 
66. Fitting J, Killian D, Junghanss C, Willenbrock S, Murua Escobar H, Lange $\mathrm{S}$, et al. Generation of recombinant antibody fragments that target canine dendritic cells by phage display technology. Vet Compar Oncol. (2011) 9:18395. doi: 10.1111/j.1476-5829.2010.00246.x

67. Alvarez B, Poderoso T, Alonso F, Ezquerra A, Dominguez J, Revilla C. Antigen targeting to APC: from mice to veterinary species. Dev Comp Immunol. (2013) 41:153-63. doi: 10.1016/j.dci.2013.04.021

68. Poderoso T, Martinez P, Alvarez B, Handler A, Moreno S, Alonso F, et al. Delivery of antigen to sialoadhesin or CD163 improves the specific immune response in pigs. Vaccine (2011) 29:4813-20. doi: 10.1016/j.vaccine.2011.04.076

69. Revilla C, Poderoso T, Martinez P, Alvarez B, Lopez-Fuertes L, Alonso $\mathrm{F}$, et al. Targeting to porcine sialoadhesin receptor improves antigen presentation to $\mathrm{T}$ cells. Vet Res. (2009) 40:14. doi: 10.1051/vetres: 2008052

70. Deloizy C, Fossum E, Barnier-Quer C, Urien C, Chrun T, Duval A, et al. The anti-influenza M2e antibody response is promoted by XCR1 targeting in pig skin. Sci Rep. (2017) 7:7639. doi: 10.1038/s41598-01707372-9
71. Harmsen MM, Van Solt CB, Fijten HP, Van Setten MC. Prolonged in vivo residence times of llama single-domain antibody fragments in pigs by binding to porcine immunoglobulins. Vaccine (2005) 23:4926-34. doi: 10.1016/j.vaccine.2005.05.017

72. Ruberti F, Bradbury A, Cattaneo A. Cloning and expression of an anti-nerve growth factor (NGF) antibody for studies using the neuroantibody approach. Cell Mol. Neurobiol. (1993) 13:559-68. doi: 10.1007/BF00711464

Conflict of Interest Statement: The authors declare that the research was conducted in the absence of any commercial or financial relationships that could be construed as a potential conflict of interest.

Copyright (c) 2018 Bustamante-Córdova, Melgoza-González and Hernández. This is an open-access article distributed under the terms of the Creative Commons Attribution License (CC BY). The use, distribution or reproduction in other forums is permitted, provided the original author(s) and the copyright owner(s) are credited and that the original publication in this journal is cited, in accordance with accepted academic practice. No use, distribution or reproduction is permitted which does not comply with these terms. 